Kalpa Publications in Civil Engineering
Volume 1, 2017, Pages 381-387
$\begin{gathered}\text { ICRISET2017. International Conference on Re- } \\ \text { search and Innovations in Science, Engineering } \\ \text { \&Technology. Selected papers in Civil Engineering }\end{gathered}$

\title{
Analysis of Mix Design of Concrete Using Ceramic Waste and Rice Husk Ash
}

\author{
M Faizan Dhrolwala ${ }^{1}$, Kaushik Kanani $^{2}$, Divyesh Patel ${ }^{3}$ and Dharti Soni ${ }^{4}$ \\ ${ }^{1,2,3}$ Student, Civil Engineering Dept., Vadodara Institute of Engineering. \\ ${ }^{4}$ Assistant Professor, Civil Engineering Dept., Vadodara Institute of Engineering. \\ dhrolwala@gmail.com, kananikaushik001@gmail.com,divscvl31@gmail.com, \\ dharti924@gmail.com
}

\begin{abstract}
This paper presents an experimental study on the properties of concrete containing ceramic wastes and rice husk ash. The ceramic industry inevitably generates wastes, irrespective of the improvements introduced in manufacturing processes, in the ceramic industry, about $15 \%-30 \%$ production goes as waste. In India during the milling of paddy about $78 \%$ of weight is received as rice, broken rice and bran, the rest $22 \%$ of the weight of paddy is received as husk, the $25 \%$ of the weight of this husk is converted into ash during the firing process, which is known as rice husk ash (RHA). These wastes causes problem in present day society, requiring a suitable form of management in order to achieve sustainable development. In this research study the (OPC) cement has been replaced by ceramic waste powder \& RHA accordingly in the range of $0 \%, 5 \%, 7.5 \%, 10 \% \& 0 \%, 5 \%, 10 \%, 12 \%$ respectively. Ceramic aggregate has been replaced by ceramic waste aggregate accordingly in the range of $0 \%, 5 \%$, $10 \%, 15 \%, 20 \%$ by weight for M- 25 grade concrete. Compressive Strength test was carried out on hardened concrete cubes after 7 and 28 days curing in water. Results show that concrete with partial cement and aggregate replacement by ceramic powder, RHA and ceramic aggregate has although minor strength loss but possesses increase in its durability performance. In current paper the analysis of various properties of ceramic aggregates, ceramic powder and RHA is carried out to validate adoptability of the same as normal aggregates and fine powder(cement) respectively. In both cases, sustainable efforts were made to reduce the quantity of material used in concrete. Reuse of this kind of waste has advantages in aspect of economic and environmental, reduction in the number of natural spaces employed as refuse dumps. Indirectly, all the above contributes to a better quality of life for citizens and to introduce the concept of sustainability in the construction sector.
\end{abstract}

C.D. Modhera, G.J. Joshi, D. Soni, I.N. Patel, A.K. Verma, L.B. Zala, S.D. Dhiman, D.R. Bhatt, J.M. Rathod, B.C. Goradiya, M.S. Holia and D.K. Patel (eds.), ICRISET2017 (Kalpa Publications in Civil Engineering, vol. 1), pp. 381-387 


\section{Introduction}

The basic materials that consist of concrete are cement, fine aggregate, coarse aggregate, water, admixture. Replacing these constituents with locally available materials which are of low cost and still providing the feasible strength are welcomed in this in new era of advancement. The present study involves understanding the behavior and performance of ceramic waste in concrete. The need to reduce the high cost of concrete requires intensified research into the use of locally available materials that could be used as partial replacement for Ordinary Portland Cement (OPC) as well as the aggregate which is use in construction work.

In India, the amount of waste in the different production stages of the ceramic industry reaches nearly to $3-7 \%$ of its global production meaning millions of tons of calcined-clays per year that are just land filled ${ }^{[1]}$. Indian ceramic production is 100 Million ton per year. In the ceramic industry, about $15 \%-20 \%$ waste material is generated from the total production ${ }^{[4]}$. This waste is not recycled in any form at present. However, the ceramic waste is durable, highly resistant to biological, chemical, and physical degradation forces. The Ceramic industries dump the waste in any nearby pit or vacant spaces, near their unit although notified areas have been marked for dumping. This leads to serious environmental and dust pollution and occupancy of a vast area of land, especially after the powder dries up, so it is necessary to dispose the ceramic waste quickly. Ceramic waste is produced from ceramic industry as the end product of polishing and finishing. The principle waste coming from the ceramic industry is the ceramic powder. Ceramic wastes are generated as a waste during the process of dressing and polishing. It is estimated that 15 to $30 \%$ waste is generated during production of raw material ${ }^{[5]}$, and although a portion of this waste is utilized on-site for refilling excavation pit. The disposal of these waste materials acquires large land areas and remains scattered all around, spoiling the aesthetic of the entire region.In India during the milling of paddy about $78 \%$ of weight is received as rice, broken rice and bran, the rest $22 \%$ of the weight of paddy is received as husk, the $25 \%$ of the weight of this husk is converted into ash during the firing process, which is known as rice husk ash (RHA). India is a major rice producing country, and the husk generated during milling is mostly used as a fuel in the boilers for processing paddy, producing energy through direct combustion and or by gasification. About 20 million tons of RHA is produced annually. This RHA is a great environment threat causing damage to the land and the surrounding area in which it is dumped. Lots of ways are being thought of for disposing it by making commercial use of this RHA. Fig. 1 shows the ceramic waste powder which is used in current research. Rice husk ash is shown in Fig. $2^{[6]}$.



Figure 2: Ceramic powder

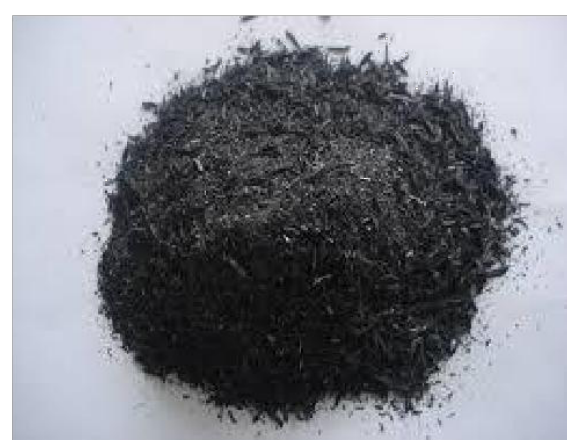

Figure 1: Rise husk ash 


\section{Materials Used}

\subsection{Cement}

The Ordinary Portland Hathi cement 53 grade conforming to IS: 12269:1987 has being used. Normal consistency of cement is $30 \%$, initial setting time is 78 minute, final setting time is 152 minute and specific gravity is 3.15 .

\subsection{Ceramic waste powder}

Ceramic waste is produced from ceramic industry at the end process of polishing and finishing. This ceramic slurry waste is avail from Morbi ceramic area, Gujarat. The material cost negligible. But the processing of the same for usage as raw material for construction industry adds up a little bite. This waste was available in the form of paste and after drying and hand crushing it was passed through 90 microns and used as cement replacement. Specific gravity of ceramic waste powder is 2.33 , water absorption is 2.4 and chemical property is as shown below:

TABLE 1: Chemical composition of ceramic waste powder

\begin{tabular}{|c|c|}
\hline Materials & Ceramic Powder (\%) \\
\hline Silicon Dioxide $\left(\mathrm{SiO}_{2}\right)$ & 78.20 \\
\hline Aluminum Oxide $\left(\mathrm{Al}_{2} \mathrm{O}_{3}\right)$ & 0.820 \\
\hline Iron Oxide $\left(\mathrm{Fe}_{2} \mathrm{O}_{3}\right)$ & 4.32 \\
\hline Calcium Oxide $(\mathrm{CaO})$ & 1.510 \\
\hline Magnesium Oxide $(\mathrm{MgO})$ & 3.580 \\
\hline Chloride $(\mathrm{CL})$ & 0.302 \\
\hline Sulphur as Sulphur Trioxide $\left(\mathrm{SO}_{3}\right)$ & 0.064 \\
\hline Loss of Ignition & 3.590 \\
\hline
\end{tabular}

\subsection{Rise husk ash (RHA)}

Rice Husk Ash used in the present experimental study was obtained from India Mart. Specifications, Physical Properties of this RHA are given in Table 2. 
Table 2: Physical properties of procured Rice Husk Ash

\begin{tabular}{|l|l|}
\hline Physical State & Solid - Non Hazardous \\
\hline Appearance & Very fine powder \\
\hline Particle Size & 25 microns - mean \\
\hline Color & Grey \\
\hline Odour & Odorless \\
\hline Specific Gravity & 2.3 \\
\hline
\end{tabular}

\subsection{Coarse aggregate}

Locally available $20 \mathrm{~mm}$ size aggregate is used. Physical property is determined, specific gravity of coarse aggregate is 2.8 , and fineness modulus is 6.9 .

\subsection{Fine aggregate}

Locally a v a i 1 a b 1 e river sand is used. As per IS 383:1970, sand is confirming to Zone III. Specific gravity of the sand used is 2.69 and the water absorption value is $0.45 \%$.

\subsection{Water}

Water is an important ingredient of concrete as it actually participates in the chemical reaction with cement. Since it helps to from the strength giving cement gel, the quantity and quality of water are required to be looked into very carefully. In this experiment, W/C ratio is 0.48 taken.

\section{MIX DESIGN}

A mix M25 grade was designed as per Indian Standard method (IS 10262-2009) and the same was used to prepare the test samples. For M25 grade of concrete, 6 cubes were casted for each batch of A0, A1, A2, A3, A4, A5, A6, A7, A8, A9. Concrete cubes having size of $150 \mathrm{~cm} \times 150 \mathrm{~cm} \times 150 \mathrm{~cm}$ were prepared for all mixes to test 3 samples of a mix at 7 and 28 days. Slump cone test was performed on all mixes to assess the workability of concrete for different percentages of replacing materials. Compressive strength test was conducted on cubes after 7 and 28 days curing period as shown in figure no.3, for each batch, 6 samples were tested. Compressive strength of each mix is taken as average of the 3 samples.

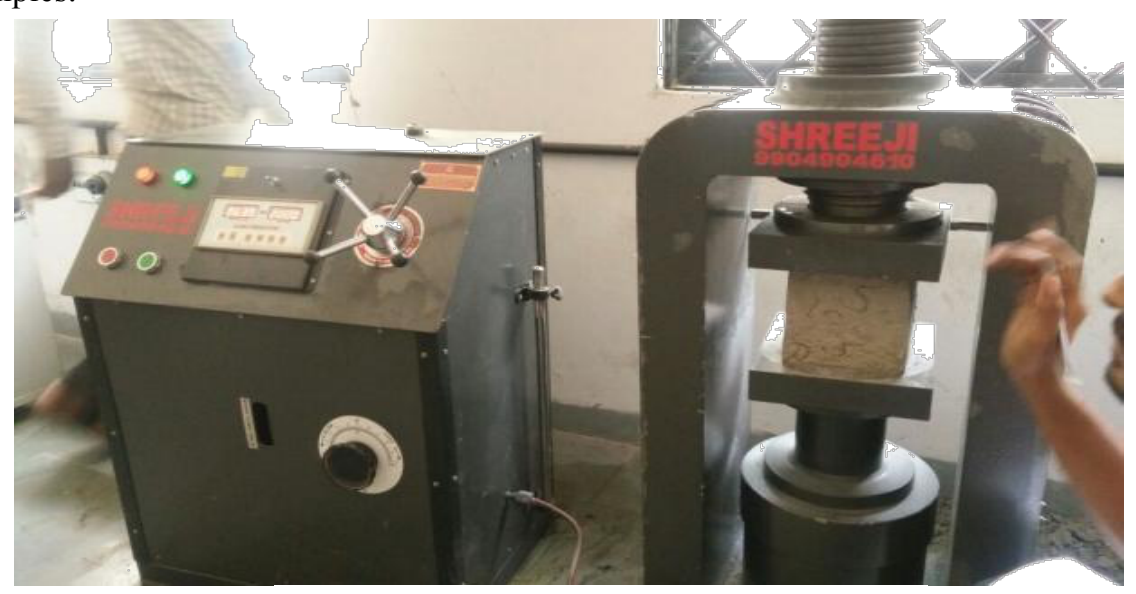

Figure 3: Compression testing machine 


\section{RESULT AND ANALYSIS}

TABLE 3: Types of concrete mix

\begin{tabular}{|c|c|c|c|c|c|c|}
\hline & \multicolumn{3}{|c|}{ Replacement of cement (\%) } & \multicolumn{2}{c|}{ Replacement of Coarse Aggregate (\%) } \\
\hline $\begin{array}{l}\text { Concrete } \\
\text { mix }\end{array}$ & $\begin{array}{c}\text { Cement } \\
(\%)\end{array}$ & $\begin{array}{l}\text { Ceramic } \\
\text { powder } \\
(\%)\end{array}$ & $\begin{array}{c}\text { Rice } \\
\text { husk } \\
\text { ash }(\%)\end{array}$ & $\begin{array}{l}\text { Coarse } \\
\text { aggregate } \\
(\%)\end{array}$ & $\begin{array}{l}\text { Ceramic } \\
\text { aggregate } \\
(\%)\end{array}$ & $\begin{array}{l}\text { 28 Days } \\
\text { Compressive } \\
\text { strength } \\
\text { N/mm })\end{array}$ \\
\hline A0 & 100 & - & - & 100 & - & $\mathbf{2 5 . 8 8}$ \\
\hline A1 & 100 & - & - & 95 & 5 & $\mathbf{2 5 . 7 7}$ \\
\hline A2 & 100 & - & - & 90 & 10 & $\mathbf{2 5 . 3 2}$ \\
\hline A3 & 100 & - & - & 85 & 15 & $\mathbf{2 4 . 8 9}$ \\
\hline A4 & 100 & - & - & 80 & 20 & $\mathbf{2 4 . 5 9}$ \\
\hline A5 & 95 & 5.0 & - & 100 & - & $\mathbf{2 5 . 0 8}$ \\
\hline A6 & 92.5 & 7.5 & - & 100 & - & $\mathbf{2 5 . 4 8}$ \\
\hline A7 & 90 & 10.0 & - & 100 & - & $\mathbf{2 4 . 9 8}$ \\
\hline A8 & 95 & - & 5 & 100 & - & $\mathbf{2 7 . 9 5}$ \\
\hline A9 & 90 & - & 10 & 100 & - & $\mathbf{2 9 . 6 1}$ \\
\hline A10 & 88 & - & 12 & 100 & - & $\mathbf{2 9 . 7 0}$ \\
\hline A11 & 85 & 7.5 & 10 & 85 & 15 & $\mathbf{2 4 . 7 0}$ \\
\hline
\end{tabular}

\section{THE AVERAGE COMPRESSIVE} STRENGTH RESULT OF NORMAL AND OPTIMUM CONCRETE



Figure 4: Compressive strength of cube 


\section{CONCLUSION}

Based on experimental investigations concerning the compressive strength of concrete, the following observations are made:

1) The compressive strength of M25 grade concrete decrease in some percentage when ceramic wastes and RHA are added. While adding ceramic powder and RHA in concrete as a replacement of cement up to $7.5 \%$ and $10 \%$ respectively feasible compressive strength can be achieved. While adding ceramic aggregate in concrete as a replacement of normal aggregate up to $15 \%$ feasible compressive strength can be achieved.

2) Combining ceramic powder $(7.5 \%)$, RHA $(10 \%)$ and ceramic aggregate $(15 \%)$ as replacement of cement and coarse aggregate respectively, $1.2 \%$ reduction in strength was observed. So, it becomes technically and economically feasible \& viable.

3) Construction industry can be the end user of all ceramic wastes and in this way can contribute to solve the environmental problems. The nature of construction industry, especially the concrete industry, is such that ceramic wastes can be used safely with no need for dramatic change in production and application process. It can be used in low strength and low cost construction. Therefore, the replacement of cement and aggregate in concrete by ceramic wastes represents a tremendous saving of energy and has important environmental benefits.

4) By using ceramic waste and RHA we can also utilize the wastes in construction industry which is non bio- degradable. High strength concrete can be obtained by adding different kinds of admixture. Utilization of Ceramic waste and its application are used for the development of the eco-friendly constructions.

5) On one hand, the cost of deposition of ceramic waste in landfill will be saved and on the other hand, raw materials and natural resources will be replaced, thus saving energy and protecting the environment. According to some authors the best way for the construction industry to become a more sustainable one is by using waste from other industries as building materials.

6) By replacing coarse aggregate and cement by ceramic aggregate and ceramic powder as well as RHA respectively, reduction in the cost of the material can be observed as these materials are the waste product of ceramic tiles manufacturing. Raw material is available locally and in low cost. Labours are required for collection and dumping the material to be used in construction industry. Skill labours are not required. Ceramic waste and RHA are waste product of different manufacturing item, thus can be available in low cost, compare to other admixtures used in concrete.

7) $1 \mathrm{~m}^{3}$ of concrete cost $36673 /$-Rs. , while optimum concrete has cost $28560 /$-Rs.. It means it can reduce $22 \%$ of construction cost per cubicmeter. which is very effective with economy point of view.

8) Utilization of Ceramic waste and RHA has a good horizon in sectors of rural development, low cost housing, temporary structures, infrastructural development, construction industry, material sciences. 


\section{REFERENCES}

FernandesM,SousaA,DiasA(2004)Environmentalimpact and emissions trade. Ceramic industry. A case study. Portuguese Association of Ceramic Industry APICER.

G.A. Habeeb, M.M. Fayyadh - Rice Husk Ash Concrete: the Effect of RHA Average Particle Size on Mechanical Properties and Drying Shrinkage\| Australian Journal of Basic and Applied Sciences, 3(3): 1616-1622, 2009 ISSN 1991-8178 C 2009, INSInet Publication.

Muga, H., K. Betz, 2005.

Amitkumar D. Raval, Indrajit N. Patel, Jayeshkumar Pitroda -Eco-Efficient Concretes: Use Of Ceramic Powder As A Partial Replacement Of Cement|| International Journal of Innovative Technology and Exploring Engineering, ISSN 2278-3075, Volume 3, Issue 2, July 2013.

Ceramic Manufacturing Industry, EUROPEAN COMMISSION, August 2007.

Amitkumar D. Raval, Dr.Indrajit N. Patel, Prof. Jayeshkumar Pitroda -Ceramic Waste : Effective Replacement Of Cement For Establishing Sustainable Concrete\| International Journal of Engineering Trends and Technology (IJETT) ISSN: 2231-5381 - Volume4 Issue6- June 